\title{
Rescue venoarterial ECMO in cardiogenic shock complicated by refractory cardiac arrest during percutaneous coronary intervention
}

\author{
Rihard Knafelja, Primoz Trunk ${ }^{b}$, Simon Terseglav ${ }^{c}$, Maja Sostaric ${ }^{b}$, Marko Noc ${ }^{a}$ \\ ${ }^{a}$ Center for Intensive Internal Medicine, University Medical Center, Ljubljana, Slovenia \\ ${ }^{b}$ Department of Cardiovascular Surgery, University Medical Center, Ljubljana, Slovenia \\ ' Department of Cardiology, University Medical Center, Ljubljana, Slovenia
}

\section{ARTICLE INFO}

\section{Article history:}

Received: 4 January 2014

Received in revised form: 31 January 2014

Accepted: 1 February 2014

Available online: 6 March 2014

\section{Kličová slova:}

Extrakorporální membránová

oxygenace

Kardiogenní šok

Koronární intervence

Zástava srdce

\section{SOUHRN}

Kardiogenní šok je hlavní příčinou úmrtí hospitalizovaných nemocných s akutními koronárními syndromy. $\checkmark$ současnosti je jediným způsobem léčby s prokázaným prínosem okamžitá revaskularizace, a to bud' perkutánní, nebo chirurgická. Přes nedostatek důkazů se k obnově hemodynamické stability - kromě revaskularizace - navíc běžně použivá intraaortální balonková kontrapulsace (IABP) a podávají se vasoaktivní látky. Z hlediska hemodynamiky jsou kromě IABP k dispozici ještě účinnější zařízení pro mechanickou podporu oběhu jako např. Impella, TandemHeart a venoarteriální extrakorporální membránová oxygenace (V-A ECMO). Přes absenci prokázaného př́nosu z hlediska přežití může uvedená přístrojová technika zachraňovat životy pacientů se závažným zhoršením hemodynamických parametrů na katetrizačním sále. Popisujeme př́pad hlubokého kardiogenního šoku v důsledku komplikované ischemické choroby srdeční, recidivy zástavy srdce během $\mathrm{PCl}$, zavedení IABP během $\mathrm{PCl}$ mezi epizodami zástavy srdce a úspěšné resuscitace pomocí $\mathrm{V}-\mathrm{A} \mathrm{ECMO}$. Úplné revaskularizace bylo dosaženo po zavedení přístroje pro ECMO; pacient byl propuštěn po 29 dnech bez neurologického postižení a s ejekční frakcí $40 \%$.

(c) 2014, ČKS. Published by Elsevier Urban and Partner Sp. z o.o. All rights reserved.
Keywords:

Cardiac arrest

Cardiogenic shock

Coronary intervention

Extracorporeal membrane oxygenation

\begin{abstract}
Cardiogenic shock represents the leading cause of death in hospitalized patients with acute coronary syndromes. Immediate revascularization, either percutaneous or surgical, currently represents the only intervention of proven benefit. Despite the lack of such proof, intra-aortic balloon pump (IABP) and vasoactive drugs are typically used to improve hemodynamic stability on top of revascularization. Mechanical circulatory support devices beyond IABP such as Impella, TandemHeart and venoarterial extracorporeal membrane oxygenation (VA ECMO) are hemodynamically even more effective. Despite the lack of proven survival benefit, this technology might be lifesaving in case of profound hemodynamic deterioration in the catheterization laboratory. We describe a case of profound cardiac shock due to complicated coronary artery disease, recurrent cardiac arrest during $\mathrm{PCl}$, intraarrest $\mathrm{PCl}$ intra-aortic balloon pump insertion and successful resuscitation after venoarterial ECMO placement. Complete revascularisation was achieved following ECMO insertion and patient was discharged home on day 29 with no neurological sequelae with ejection fraction of $40 \%$.
\end{abstract}




\section{Introduction}

Cardiogenic shock represents the leading cause of death in hospitalized patients with acute coronary syndromes. Immediate revascularization, either percutaneous or surgical, currently represents the only intervention with randomized proof of benefit [1]. Despite the lack of such evidence, intra-aortic balloon pump (IABP) and vasoactive drugs are typically used to improve hemodynamic stability on top of revascularization [2,3]. Mechanical circulatory support devices beyond IABP such as Impella, TandemHeart and venoarterial extracorporeal membrane oxygenation (VA $E C M O)$ are hemodynamically more effective and, despite the lack of proven survival benefit, this technology is frequently used as a rescue strategy in patients with profound hemodynamic collapse [4-11]. We herein report a patient with cardiogenic shock complicated by refractory cardiac arrest during percutaneous coronary intervention $(\mathrm{PCl})$ in whom percutaneous VA ECMO insertion in the catheterization laboratory proved to be lifesaving.

\section{Case report}

A 52-year-old active smoker with hyperlipidemia but without history of coronary artery disease was brought to the community hospital by emergency prehospital team. His complaint was severe dyspnoea and chest pain escalating during the last 3 days. Except for acetylsalicylic acid $100 \mathrm{mg}$ and ezetimibe $10 \mathrm{mg} / \mathrm{simvastatin} 20 \mathrm{mg}$, he was not taking any regular medication. Electrocardiogram (ECG) recorded by the prehospital unit revealed ST elevation in $\mathrm{V}_{1-3}$ and, notably, elevation in aVR together with depression in $\mathrm{V}_{5-6}$ (Fig. 1A). An evolving pulmonary edema was diagnosed and since it was refractory to morphine, furosemide and oxygen, endotracheal intubation was performed and mechanical ventilation initiated soon after hospital admission. Because of hypotension, norepinephrine infusion was also added. Repeat ECG revealed resolution of ST-elevation in precordial leads but not in aVR, and ST-depression in several other leads (Fig. 1B). Cardiac troponin $\mathrm{T}(\mathrm{TnT})$ was only slightly elevated $(0.32$ $\mu \mathrm{mol} / \mathrm{L}$, normal $<0.013 \mu \mathrm{mol} / \mathrm{L})$. Our hospital was alerted for immediate coronary angiography and the patient was transported by ambulance within $50 \mathrm{~min}$.

On the admission to our hospital, transesophageal echocardiography was immediately performed to exclude possible mechanical defect (i.e. mitral chordae or papillary muscle rupture). Apical akinesia and diffuse hypokinesia of anterolateral wall with left ventricular ejection fraction below $30 \%$ and significant mitral regurgitation without flail leaflet were documented. The patient was then transported to the catheterization laboratory. Despite norepinephrine and dobutamine, initial aortic pressure was $100 / 75$ and heart rate $130 \mathrm{bpm}$. Coronary angiography revealed severe diffuse obstructive coronary disease with eccentric $60 \%$ ostial left main (LM) stenosis, occlusion of left anterior descending artery (LAD) after the first septal branch with some collaterals to the distal vessel (Rentrop $1-2$ ), occluded first diagonal branch, long $90-95 \%$ ostial stenosis of medium sized first obtuse marginal branch, $99 \%$ stenosis of large second obtuse marginal branch with TIMI 3 and proximal chronic total occlusion of the dominant right coronary artery (RCA) with predominately left to right collaterals (Fig. 2). Based on prehospital ECG and echocardiography with evidence of apical akinesia/anterolateral hypokinesia, LAD was considered as a culprit vessel. The plan was to restore $L A D$ patency and improve hemodynamic status followed by $\mathrm{PCl}$ of second obtuse
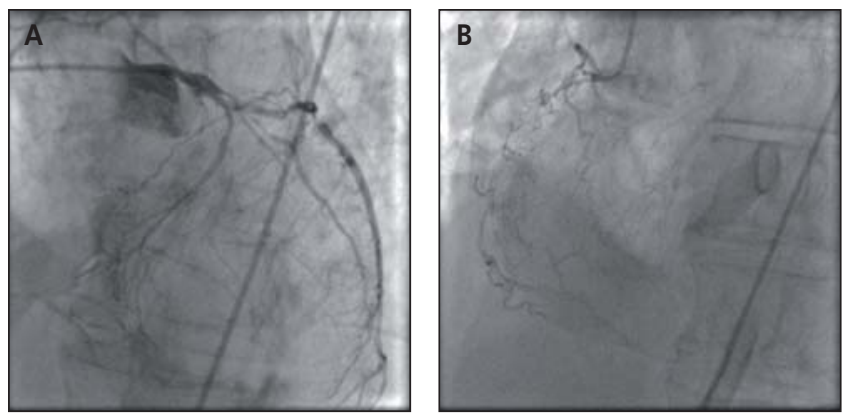

Fig. 2 - Immediate coronary angiography of the left (A) and right (B) coronary artery.
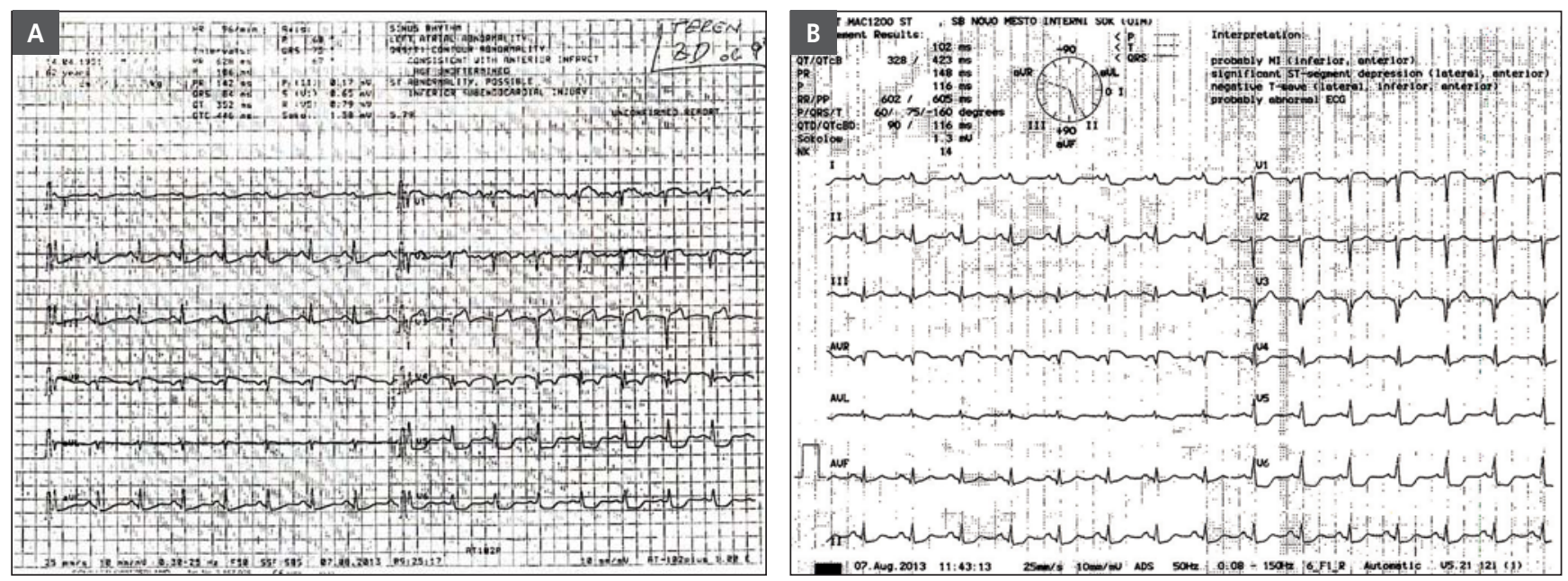

Fig. 1 - Prehospital electrocardiogram (A) and electrocardiogram after hospital admission, intubation, mechanical ventilation and norepinephrine infusion. 


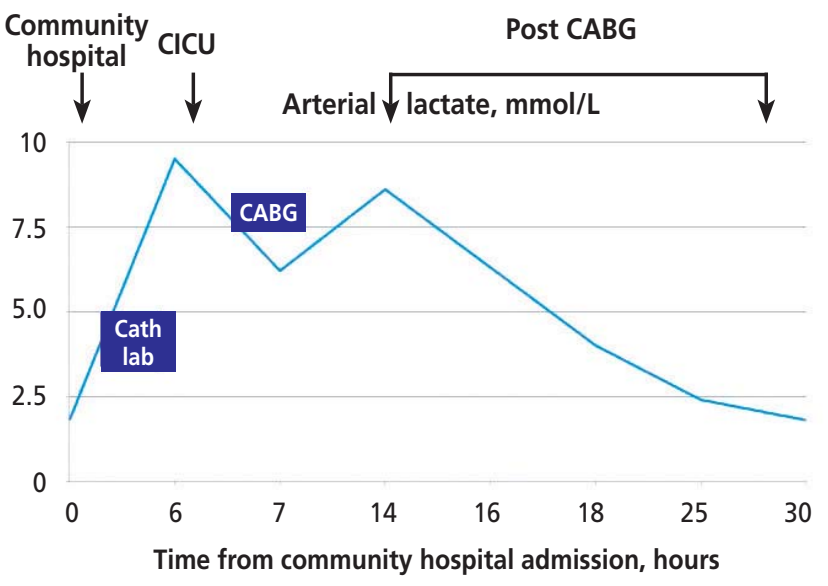

Fig. 3 - Arterial lactate concentration during initial $30 \mathrm{~h}$ after the first presentation.

marginal. The patient received unfractioned heparin according to activated clotting time and JL $46 \mathrm{Fr}$ guiding catheter was used to engage left coronary artery without ventricularization of pressure tracing. A standard working horse guide-wire (Advance, Abbott Vascular) was passed across the occlusion with the support of Minitrack $2.0 \mathrm{~mm}$ $\times 15 \mathrm{~mm}$ balloon (Abbott Vascular). Following few balloon inflations patency of LAD with TIMI 1-2 was restored. Despite this, hemodynamic status further deteriorated to pulseless electrical activity. Chest compression was initiated, epinephrine boluses administered and norepinephrine infusion increased. Effectiveness of chest compression was assured by continuous monitoring of the aortic pressure. After approximately 5 minutes, spontaneous circulation was restored. Intraaortic balloon pump (IABP) using 7.5 Fr 40 cc linear balloon catheter (Maquet Getinge Group) was inserted through the left femoral artery and epinephrine infusion added to already existing vasopressor/ inotropic support. Transient hemodynamic stabilization was followed by recurrent cardiac arrest which was this time refractory to conventional cardiac life support. During ongoing cardiopulmonary resuscitation which only transiently restored spontaneous circulation, VA ECMO was implemented. In brief, guiding catheter was removed from right femoral artery and 6 Fr sheath exchanged for $17 \mathrm{Fr}$ arterial cannula after sequential dilatation using Seldinger technique. The tip of the arterial cannula was placed at the aortic bifurcation. Anterograde puncture of ipsilateral superficial femoral artery for sheath insertion to prevent limb ischemia was, due to urgency of the situation and lack of pulsative flow, abandoned. A $21 \mathrm{Fr}$ venous cannula was inserted through the left femoral vein using the same percutaneous technique. The tip was positioned at the entry into the right atrium. VA ECMO (CardioHelp, Maquet Getinge Group) was started and "rpm" increased to 3600 resulting in $3.54 \mathrm{~L} / \mathrm{min}$ retrograde aortic flow. IABP was maintained at $1: 1$ ratio. The total time from onset of refractory cardiac arrest to VA ECMO "jump start" was 30 to $35 \mathrm{~min}$. Because of prolonged cardiac resuscitation and persistent coma despite reestablishment of cerebral perfusion, cooling using VA ECMO circuit was initiated to reach a target temperature between 32 and 34 C [12]. Cardiac surgeon was called in the catheterization laboratory and decision was made to proceed with emergency CABG. Since all operating rooms were occupied, the patient was transiently transported to cardiac intensive care unit. Epinephrine infusion could have been discontinued and norepinephrine/dobutamine significantly reduced. Excessive urinary output $(600 \mathrm{ml})$ was documented already within initial two hours. Arterial lactate, which was within normal limits in referring hospital, increased to a maximum of $9.5 \mathrm{mmol} / \mathrm{L}$ (Fig. 3). Cardiac troponin I (Tnl) before CABG was $3.99 \mu \mathrm{mol} / \mathrm{L}$ (normal $<0.06 \mu \mathrm{mol} / \mathrm{L}$ ). After 4 hours in intensive care unit, the patient was transported to the operating room. Levosimendan infusion was started and VA ECMO was replaced with conventional heart-lung machine using the same cannulas. LAD was grafted by LIMA. Large obtuse marginal and RCA were grafted by safenous vein grafts. Since left ventricular function did not improve after CABG, VA ECMO and IABP were re-started and the patient transferred to intensive care unit. Arterial lactate normalized within $30 \mathrm{~h}$ (Fig. 3) and urinary output was normal. Tnl increased to a maximum of 22.48 during the first postoperative day. Postoperative course was complicated by bleeding at the site of arterial cannula requiring intervention on the second postoperative day, malignant ventricular arrhythmias with ventricular fibrillation requiring coronary angiography to confirm grafts patency on day 3 , nosocomial infections requiring treatment with several antimicrobial drugs and paroxysmal atrial fibrillation/undulation treated with amiodarone. Left ventricular function gradually improved and allowed successful weaning from ECMO on day 14 facilitated by IABP which was removed on day 15 . Mechanical ventilation followed by tracheal extubation was discontinued on day 20. The total duration of intensive care stay was 24 days. The patient was discharged from our hospital 29 days after the index event with normal neurocognitive status. Except for limited area of akinesia of the apical part of inter-ventricular septum, echocardiography revealed normalization of ejection fraction and only non-significant mitral regurgitation. Five months after the index event, the patient is living his normal life (NYHA) and has an ejection fraction of $40 \%$.

\section{Discussion}

We herein describe previously healthy man with acute coronary syndrome and very complex coronary disease presenting with pulmonary edema followed by cardiogenic shock and refractory cardiac arrest during $\mathrm{PCl}$ attempt. After failure of advanced cardiac life support, VA ECMO was lifesaving and allowed for urgent CABG, reversal of cardiogenic shock within $24 \mathrm{~h}$ and bought time for myocardial recovery following revascularization.

Looking retrospectively, the best solution for this patient would have probably been immediate hemodynamic support by IAPB or VA ECMO followed by complete surgical revascularisation without $\mathrm{PCl}$ attempt. The reason for hemodynamic deterioration during $\mathrm{PCl}$ might have been accidental deep engagement of the guiding catheter into the stenosed LM during $\mathrm{PCl}$ or balloon withdrawal. Despite successful initial resuscitation, cardiac arrest undoubtedly worsened already existing cardiogenic shock which ultimately progressed to refractory cardiac 
arrest. Despite the lack of randomized data, we can speculate that this complication might have been avoided by implementation of hemodynamic support prior to $\mathrm{PCl}$ attempt $[13,14]$ or if we immediately decided for emergency CABG without PCl attempt.

After hemodynamic stabilization with VA ECMO, we were faced with the dilemma regarding the timing of CABG since "acute heart team" in the catheterization laboratory felt that further $\mathrm{PCl}$ attempts will not represent the optimal revascularization option. At that point, one possibility was to wait with CABG for few days to reverse cardiogenic shock by ECMO and document neurological recovery after cardiac arrest. However, since we suspected LAD occlusion to be acute, such a delay may have resulted in large, unreperfused anterior infarction. Since peak $\mathrm{Tnl}$ increased only to $22 \mu \mathrm{mol} / \mathrm{L}$ after CABG, which is 10-20 times less what we usually expected in such acute LAD occlusion, the infarct was either largely aborted by timely CABG or LAD occlusion has not been the culprit despite initial ECG, echocardiography and ability to cross occlusion without dedicated CTO wire. Indeed, the culprit might have been also large obtuse marginal branch with spontaneous re-perfusion before coronary angiography. However, it is important to notice that in the setting of so complex multi-vessel disease, the culprit lesion may not be unequivocally identified, and in fact, multiple culprits are also possible [15]. From the interventional point of view, however, we believe that correct identification of culprit lesion is important since this lesion should be primary treated followed by non-culprit lesions advised by the guidelines [15]. Complete revascularization seems to be important also in cardiogenic shock complicated by cardiac arrest which was the case in our patient [15]. Since this could have been hardly achieved during index $\mathrm{PCl}$, emergency CABG was decided by the our "acute heart team" and should not be forgotten as a potential solution in the presence of complex coronary disease despite profound hemodynamic collapse.

Nowadays, there is increasing evidence predominantly coming from far east that refractory cardiac arrest, even in the prehospital setting, may be successfully stabilized by VA ECMO which buys time for subsequent revascularization with remarkable $10-20 \%$ survival with good neurological outcome $[16,17]$. In fact, such hyper-invasive strategy in patients with out-of-hospital cardiac arrest and no return of spontaneous circulation is currently being tested in the randomized fashion [18]. If such catastrophic situation occurs in the cath laboratory such as in our patient, immediate VA ECMO insertion can be faster and more easily accomplished than either on the field or in emergency department [4-7]. Instead of surgical cut down, percutaneous insertion of cannulas by interventional cardiologist without is rather straight forward and safe even in the absence of pulsative flow since $X$-ray may be used to control position of the wire and advancement of ECMO cannulas even during ongoing chest compression. It is very important to emphasize, however, that delay between cardiac arrest and "jump start" by VA ECMO should be as short as possible because this will reduce the severity of post-resuscitation brain injury and post-resuscitation systemic inflammatory response leading to multiple organ dysfunction. Since pre-primed ECMO is rarely available, ECMO priming should be performed in parallel with insertion of arterial and venous cannulas by additional team. Assist devices such as Impella, which is inserted into the left ventricle and does not need oxygenator, are even more user friendly [11]. We therefore believe that temporary circulatory assist devices may in the near future become a standard of care in "24-7" catheterization laboratories treating patients with acute coronary syndromes. This would allow for hemodynamic stabilization followed by $\mathrm{PCl}$ also in patients with profound cardiogenic shock and cardiac arrest thereby providing a realistic chance for survival $[18,19]$.

\section{Conflict of interest}

All authors (Rihard Knafelj, Primoz Trunk, Simon Terseglac, Maja Sostaric, Marko Noc) declare no conflict of interest considering case report, methods, materials or equipment used.

\section{Funding body}

All authors (Rihard Knafelj, Primoz Trunk, Simon Terseglac, Maja Sostaric, Marko Noc) declare that none of the materials or equipment described in the article was funded by the industry. There was no financial support from industry regarding preparation of this paper.

\section{Ethical statement}

All authors (Rihard Knafelj, Primoz Trunk, Simon Terseglac, Maja Sostaric, Marko Noc) declare that during treating the patient described in this case report strict ethical principles were applied.

\section{Informed consent}

Since the paper submitted isn't characterized as a research paper we did not search for nor obtained informed consent.

\section{References}

[1] J.S. Hochman, L.A. Sleeper, J.G. Webb, et al., Early revascularization in acute myocardial infarction complicated with cardiogenic shock. SHOCK Investigators. Should We Emergently Revascularize Occluded Coronaries for Cardiogenic Shock, New England Journal of Medicine 341 (1999) 625-634.

[2] H. Thiele, U. Zeymer, F.J. Neumann, et al., Intraaortic balloon support for myocardial infarction with cardiogenic shock, New England Journal of Medicine 367 (2012) 1287-1296.

[3] S.R. Finfer, J.L.Vincent, Circulatory shock, New England Journal of Medicine 369 (2013) 1726-1734.

[4] M.R. Mooney, K.V. Arom, L.D. Joyce, et al., Emergency cardiopulmonary bypass support in patients with cardiac arrest, Journal of Thoracic and Cardiovascular Surgery 101 (1991) 450-454.

[5] J.G. Powney, R.S. Bonser, S. Lentini, Emergency coronary artery surgery after refractory cardiac arrest: a single centre experience, British Heart Journal 67 (1992) 392-394.

[6] Y. Mori, K. Ueno, A. Hattori, et al., Emergency cardiopulmonary bypass in patients with cardiac arrest caused by myocardial infarction, Artificial Organs 18 (1994) 698-701.

[7] M.J. Ricciardi, M. Moscucci, B.P. Knight, et al., Emergency extracorporeal membrane oxygenation (ECMO)-supported percutaneous coronary interventions in fibrillating heart, Catheterization and Cardiovascular Interventions 48 (1999) 402-405.

[8] H. Sunami, Y. Fujita, T. Okada, et al., Successful resuscitation from prolonged ventricular fibrillation using a portable 
percutaneous cardiopulmonary support system, Anesthesiology 99 (2003) 1227-1229.

[9] Y. Matsunari, H. Imanaka, M. Takeuchi, et al., Recovery from fatal ventricular fibrillation after immediate application of percutaneous cardiopulmonary support, Masui 53 (2004) 795-798.

[10] K. Sung, Y.T. Lee, P.W. Park, et al., Improved survival after cardiac arrest using emergent auto-priming percutaneous cardiopulmonary support, Annals of Thoracic Surgery 82 (2006) 651-656.

[11] V.K. Mukku, Q. Cai, S. Gilani, et al., Use of Impela ventricular assist device in patients with severe coronary artery disease presenting with cardiac arrest, International Journal of Angiology 21 (2012) 163-166.

[12] The Hypothermia After Cardiac Arrest (HACA) Study Group, Mild therapeutic hypothermia to improve the neurological outcome after cardiac arrest, New England Journal of Medicine 346 (2002) 549-556.

[13] D. Perera, R. Stables, M. Thomas, et al., Elective intra-aortic balloon counter-pulsation during high-risk percutaneous coronary intervention, Journal of the American Medical Association 304 (2010) 867-874.

[14] W.W. O'Neill, N.S. Kleiman, J. Moses, et al., A prospective, randomized clinical trial of hemodynamic support with Impela 2.5 versus intra-aortic balloon pump in patients undergoing high-risk percutaneous coronary intervention. The PROTECT II study, Circulation 126 (2012) 1717-1727.
[15] D. Mylotte, M.C. Morice, H. Eltchaninoff, et al., Primary percutaneous coronary intervention in patients with acute myocardial infarction, resuscitated cardiac arrest and cardiogenic shock: the role of primary multivessel revascularization, JACC: Cardiovascular Interventions 6 (2013) 115-125.

[16] K. Nagao, N. Hayashi, K. Kanmatsuse, et al., Cardiopulmonary cerebral resuscitation using emergency cardiopulmonary bypass, coronary reperfusion therapy and mild hypothermia in patients with cardiac arrest outside the hospital, Journal of the American College of Cardiology 36 (2000) 776-783.

[17] Y.S. Chen, A. Chao, H.Y. Yu, et al., Analysis and results of prolonged resuscitation in cardiac arrest patients rescued by extracorporeal membrane oxygenation, Journal of the American College of Cardiology 41 (2003) 197-203.

[18] J. Belohlavek, K. Kucera, J. Jarkovsky, et al., Hyperinvasive approach to out-of-hospital cardiac arrest using mechanical chest compression device, prehospital intraarrest cooling, extracorporeal life support and early invasive assessment compared to standard care. A randomized parallel groups comparative study proposal. "Prague OHCA study", Journal of Translational Medicine 10 (2012) 163.

[19] S.A. Bernard, T.W. Gray, M.D. Buist, et al., Treatment of comatose survivors of out-of-hospital cardiac arrest with induced hypothermia, New England Journal of Medicine 346 (2002) 557-563. 